\title{
Utilizing Methane Generated in Anaerobic Leachate Treatment as Renewable Energy
}

\author{
Hamidreza Kamalan
}

\begin{abstract}
Methane is a main source of energy. On the other hand, it is a major greenhouse gas. This study aims to investigate generation of methane as energy source from municipal solid waste leachate anaerobic treatment through an up flow anaerobic sludge blanket system.

Results show Chemical Oxygen Demand removal has a direct relation with methane generation. It is notable that the about two third of produced biogas consists of methane. On this basis numerical models have been developed to predict methane emission based on time.
\end{abstract}

Index Terms-Energy element, methane, leachate, municipal solid waste.

\section{INTRODUCTION}

Municipal and industrial waste management are essential part of our modern life to have a safe ecosystem and sanitary society [1]. Landfill leachate have different sources such as i) moisture of the solid waste resulting of decomposition of organic matter and ii) other liquid from external sources (raining or snowing and penetration of underground water). Thus, leachate causes serious pollution and it has to be treated prior to discharging to the environment [2]. Biological treatment is widely acceptable to control the conditions and help microorganisms to grow in aerobic or anaerobic system [3].

Among the greenhouse gases, methane has 21 times the global warming potential of carbon dioxide by mass [4]. In another word, methane is the leading anthropogenic contributor to global warming after carbon dioxide. As an international concern, atmospheric methane concentrations have doubled over the last 200 years and continue to rise, although the rate of increase is slowing [5].

Methane is emitted from a variety of both human-related (anthropogenic) and natural sources. Human-related activities include fossil fuel production, animal husbandry (enteric fermentation in livestock and manure management), rice cultivation, biomass burning, and waste management. These activities release significant quantities of methane to the atmosphere. It is estimated that $60 \%$ of global methane emissions are related to human-related activities. Natural sources of methane include wetlands, gas hydrates, permafrost, termites, oceans, freshwater bodies, non-wetland soils, and other sources such as wildfires [6], [7].

Among all methane sources, landfills as a part of waste management chain are the largest human-related source of methane which is being accounted for $34 \%$ of all methane emissions. Methane is generated in landfills and open dumps as waste decomposes under anaerobic conditions [7].

Microorganisms' activities cause anaerobic digestion in the following manner. Living creatures need energy to live and grow. Therefore, they use materials and with metabolism reaction produce energy for themselves. Catabolism is decomposition of complex organic matter into simple products that release energy. Then, the released energy is consumed in oxidation by microorganisms and is reserved in cells in the form of ATP (Andesine Troposphere), a kind of biological fermentation process which has not been fully elucidate. In this process, substrates are basically fats, polysaccharides and proteins that are derived from a variety of organic junk. Fermentative bacteria hydrolyze primary substrate polymers such as polysaccharides, proteins and lipids and ferment the products mainly to acetate and other saturated fatty acids, $\mathrm{CO}_{2}$ and $\mathrm{CH}_{4}$. These processes, all together acts as a self-regulated system in order to maintain $\mathrm{pH}$ conditions, oxidation and revive potential and thermodynamic equilibrium of circumference and constancy of digestion. Accordingly, anaerobic biological process with the help of microorganisms causes decomposition of organic matter in the absence of oxygen molecule and produces anionic components such as $\mathrm{NO}^{3-}, \mathrm{SO}_{4}{ }^{2-}$ and $\mathrm{PO}_{4}{ }^{3-}$ in presence of oxygen. In this regard, when organic matter is being treated, BOD and COD products are converted to biogas that is mainly $\mathrm{CH}_{4}$ and $\mathrm{CO}_{2}$ [8], [9].

However, the investigations which have carried out by Buswell and his colleagues in 1930 to 1938 lead to a better understanding of the anaerobic process. Methane gas production and intermediate components mass balance represents methane fermentation in general as follows [1]:

$$
\begin{gathered}
\mathrm{C}_{n} \mathrm{H}_{a} \mathrm{O}_{b}+(n-a / 4-b / 2) \mathrm{H}_{2} \mathrm{O} \rightarrow(n / 2-a / 8+b / 4) \mathrm{CO}_{2}+ \\
(n / 2+a / 8-b / 4) \mathrm{CH}_{4}
\end{gathered}
$$

Three major bacterial groups are developing anaerobic digestion process: 1- Hydraulic bacteria, 2- Hetroacetogen bacteria and 3- Methanogenic bacteria.

The major effective parameter in methane production is the amount of carbon in organic part of wastewater. Microorganisms consume wastewater and carbon (in anabolism process) is converted into microbus cellular materials (assimilated carbon) and the rest of carbon (in catabolism process) is consumed to produce $\mathrm{CH}_{4}$ and $\mathrm{CO}_{2}$ (dissimilated carbon).

\section{MATERIALS AND METHODS}

Manuscript received June 18, 2014; revised August 24, 2014.
Hamidreza Kamalan is with Pardis Branch, Islamic Azad University, Tehran, Iran (e-mail: hkamalan@pardisiau.ac.ir).
When The UASB reactor (essentially just an inexpensive 
empty tank) consists of a few basic parts: i) the sludge bed, ii) settler, iii) baffles, iv) gas cap and v) three-phase separator. It has an influent inlet at the bottom and a biogas outlet at the top as well as an effluent for digested liquid. Wastewater is pumped through the inlet and flows upwards. Upon contact with the sludge bed, organics are degraded to $\mathrm{CH}_{4}$ and $\mathrm{CO}_{2}$ gas (commonly called biogas). The biogas bubbles up in the reactor along with the water until it reaches the three-phase separator, at which the water is separated from the sludge. This water moves to the bottom and the biogas, which is caught by the gas cap, is released from the reactor. The baffles (gas collectors) are made in $45^{\circ}$ to $60^{\circ}$ angle to guide the gas into the gas cap. The formation and bubbling of biogas creates hydraulic turbulence in the reactor that produces a stirring effect and naturally increases the contact between the liquid, suspended solids and the bacteria on granules. Hence, no mechanical mixing is required. Gas collectors cover all the area to contain the entire reactor effective volume [2].

The major parameters effecting UASB rector operation are: 1 - food in wastewater (C,N,P and other elements which are required for microorganisms' growth), 2- temperature, 3organic loading rate (OLR), 4- hydraulic retention time (HRT), 5- organic removal efficiency, 6- sludge retention time (SRT), 7- $\mathrm{pH}, 8-\mathrm{F} / \mathrm{M}, 9$ - trace elements, 10- toxic elements such as heavy metals, 11- alkalinity, 12- any kind of shocks (thermal shock, pollution shock,...) [10]-[12].

In this research UASB reactor has 22 liters volume and its inner diameter and height are $10.6 \mathrm{~cm}$ and $254 \mathrm{~cm}$, respectively and it is made of PVC in the cylindrical shape. It also has a three-phase separator on the top and 6 sample collecting taps in 6 appropriate places on the body to control sludge and measure any changes in system. Leachate is pumped into the reactor from a feeding tank (50 lit) that prevents granulation of the sludge within the system. Laboratory tests such as measurement of temperature, $\mathrm{pH}$, COD, BOD, TS, TVS, MLSS, MLVSS, alkalinity and VFA (volatile fatty acids) according to 1995 standard book, and biogas production rate and methane gas percentage are done in this research.

Polytector2 (G750 model) has been used to measure methane gas percentage in the out-coming biogas. This instrument has absorbing system and is hand-operated. The gas is forced into the sensor probe by a pump and through a diffusion inlet. The machine shows the percentage of some gases within the biogas such as methane, $\mathrm{CO}, \mathrm{CO}_{2}, \mathrm{H}_{2} \mathrm{~S}$ and oxygen.

In order to do anaerobic biological degradation test, the gas produced out of anaerobic treatment process is lead via a plastic pipe into a long narrow container of an alkaline solution. This method removes $\mathrm{CO}_{2}$ of the biogas and methane gas is collected and measured.

The formation of biological mass is essential to have a stable regime through biological wastewater treatment. On the other hand, in order to make an appropriate compatibility in anaerobic systems, it's suggested to examine reactor behavior under batch and then continuous regimes. Batch system is essential to obtain suitable compatibility for the sludge with particular conditions within the system, such as the growth of anaerobic microorganism through system granulation, digestion capability, organic acidic molecules' break in the shortest time, light sludge returning and reactor efficiency improvement. In this project, landfill leachate without any wastewater is used. Inoculation of approximately 4 liters combination of slaughter-house anaerobic sludge with sludge formation of leachate maintenance in a closed container for 45 days are used for acceleration in reactor start up and stabilizing equilibrium condition within the system. Then leachate is diluted to: i) increase compatibility between inoculated sludge and leachate, and ii) obtain an appropriate range of leachate loading rate (e.g.: COD and BOD). Landfill leachate particulars are presented in Table I [13].

TABLE I: KAHRIZAK LANDFILL LEACHATE PARTICULARS

\begin{tabular}{|l|l|l|}
\hline Pollutant & Amount $(\mathbf{m g} / \mathbf{l})$ & Average $(\mathbf{m g} / \mathbf{l})$ \\
\hline COD & $70000-90000$ & $\mathbf{8 0 0 0 0}$ \\
\hline BOD & $24000-38000$ & $\mathbf{3 1 0 0 0}$ \\
\hline TSS & $1000-6700$ & $\mathbf{3 8 5 0}$ \\
\hline Nitrate & $210-300$ & $\mathbf{2 5 5}$ \\
\hline $\begin{array}{l}\text { Ammonia } \\
\text { Nitrogen }\end{array}$ & $200-270$ & $\mathbf{2 3 5}$ \\
\hline Phosphate & $70-90$ & $\mathbf{8 0}$ \\
\hline Sulfate & $1600-2000$ & $\mathbf{1 8 0 0}$ \\
\hline Chloride & $\mathbf{3 8 0 0 - 4 4 0 0}$ & $\mathbf{4 1 0 0}$ \\
\hline
\end{tabular}

The system is run in batch regime for 30 days and then it is converted to continuous form for 60 days. In batch regime, COD concentration in leachate is 1200 to $6443 \mathrm{mg} / \mathrm{lit}$ and for continuous regime it reaches 5768 to $25960 \mathrm{mg} / \mathrm{l}$. Organic loading rate in this system for batch and continuous regimes is 1.36 to $6.6 \mathrm{~kg} \mathrm{COD} / \mathrm{m}^{3}$ and 5.9 to $29.5 \mathrm{~kg} \mathrm{COD} / \mathrm{m}^{3}$, respectively. All the parameters are measured every day, in summer. Therefore the temperature is suitable for anaerobic microorganisms' activities. The $\mathrm{pH}$ is 6.5 and then with addition of normal alkaline it is increased to 7 [13].

Converting the regime to continuous type is essential to obtain practical conditions and appropriate efficiency for optimum operation in high COD and assurance of methanogenic sludge activity. Prevent system shut down, Volatile Suspended Solids (VSS= active bacteria in organic material removal) decreasing based on sludge's escaping, primary preventing of fluid's existing should be done on time. In this regard and based on the liquid velocity ( 0.1 to 0.2 $\mathrm{m} / \mathrm{hr}$ ), we need retention time of 18-28 hours. After obtaining a constant removal efficiency for $\mathrm{COD}_{\text {removal }}$ and biogas production (as a confirming factor), leachate concentration is increased gradually [13].

Leachate in landfill is produced every day. In order to have a practical plan, batch regime results are omitted in this section. In continuous regime, at first OLR is $5.9 \mathrm{~kg} \mathrm{COD} / \mathrm{m}^{3}$, hydraulic retention time (HRT) equals to 24 hours and incoming COD is $5750 \mathrm{mg} / \mathrm{l}$. Then the effluent parameters reach $29.5 \mathrm{~kg} \mathrm{COD} / \mathrm{m}^{3}, 22 \mathrm{hr}$ and $25960 \mathrm{mg} / \mathrm{l}$, at the end of the study, respectively [13].

In Fig. 1 influent COD is shown in correlation with effluent COD. When $\mathrm{COD}_{\text {in }}$ is increased, $\mathrm{COD}_{\text {out }}$ increases too but after a short time due to enhancement of microorganisms' compatibility, $\mathrm{COD}_{\text {out }}$ decreases gradually. In order to obtain more biogas without shocks, OLR and $\mathrm{COD}_{\text {in }}$ are increasing gradually. Fig. 2 shows that variation of $\mathrm{COD}_{\text {removal }}$ and methane production has similar behavior. Methane gas volume is constant percentage of biogas production volume, and $\mathrm{COD}_{\text {removal }}$ is proportional to biogas production volume. 
Fig. 3 and Fig. 4 illustrate methane gas volume variations (lit/day) in correlation with organic loading rate $\left(\mathrm{kg} \mathrm{COD} / \mathrm{m}^{3}\right)$ and $\mathrm{COD}_{\text {removal }}$ efficiency, respectively. At the beginning, the produced biogas volume is low and after a short time period, due to enhancement of microorganisms and reactor circumstances compatibility, the gas volume increases. As illustrate in Fig. 3 and Fig. 4, at the beginning OLR is equal to $5.9 \mathrm{~kg} \mathrm{COD} / \mathrm{m}^{3}$, efficiency of system is $72.9 \%$ and biogas and methane gas production rate are $66583 \mathrm{ml} /$ day and 49272 $\mathrm{ml} /$ day, respectively. Increasing influent COD up to 8395 $\mathrm{mg} / \mathrm{l}$ and OLR to $7.1 \mathrm{~kg} \mathrm{COD} / \mathrm{m}^{3}$, the efficiency decreases to $48 \%$, and biogas and methane gas production rate decrease to $31633 \mathrm{ml} /$ day and $23409 \mathrm{ml} /$ day, respectively. After this stage when we increase OLR and COD, the removal efficiency varies between 40 to $60 \%$ [13].

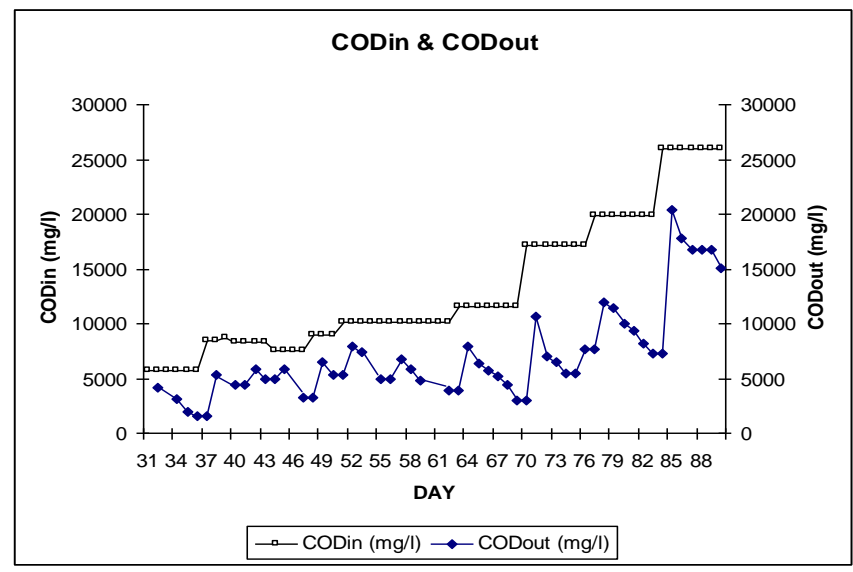

Fig. 1. $\mathrm{COD}_{\text {in }}$ and $\mathrm{COD}_{\text {out }}$ in continuous regime.

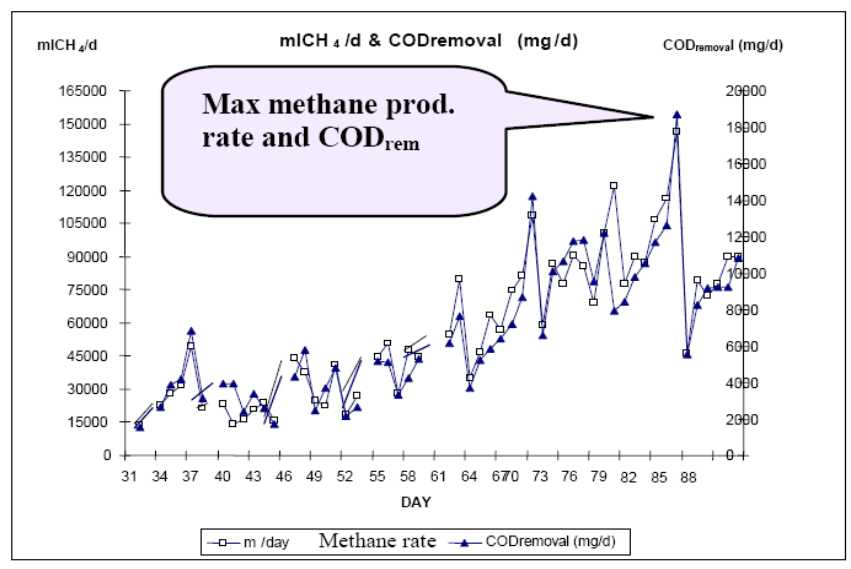

Fig. 2. Methane production rate and $\mathrm{COD}_{\text {removal }}$.

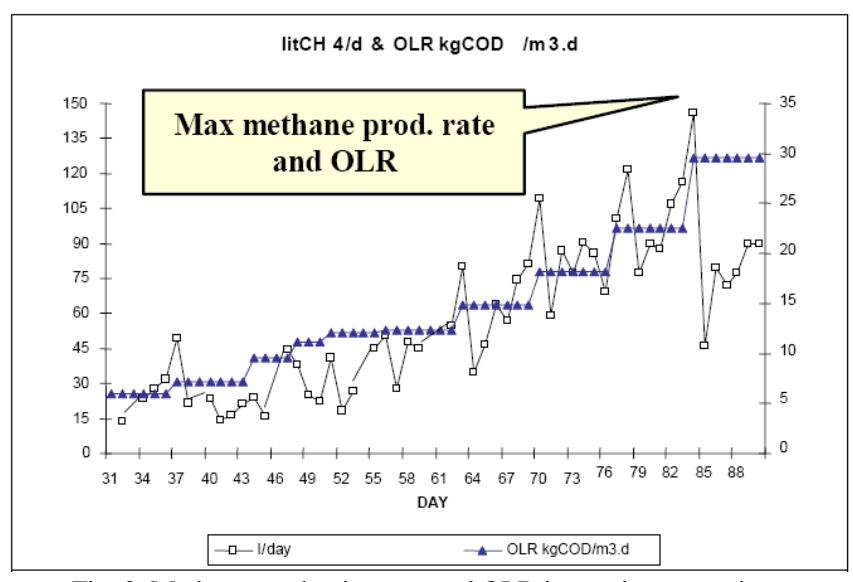

Fig. 3. Methane production rate and OLR in continuous regime.

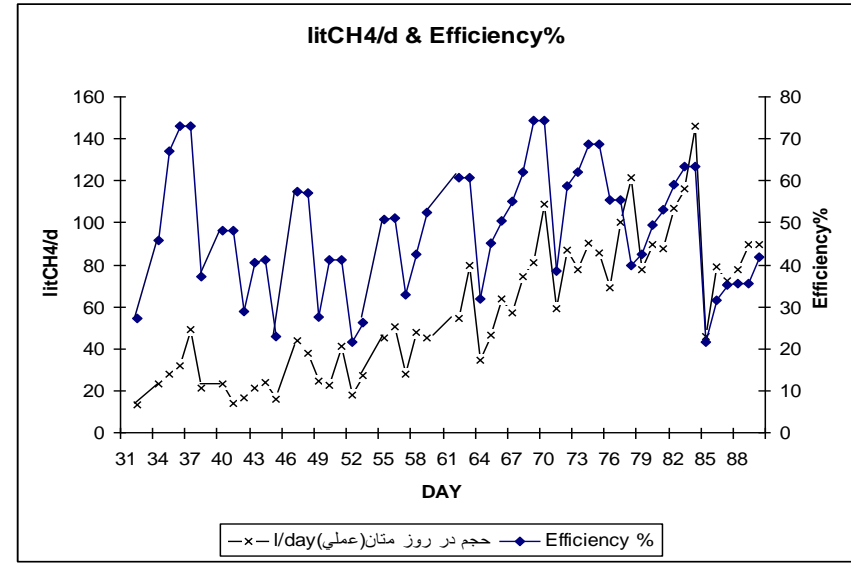

Fig. 4. Methane production rate and efficiency.

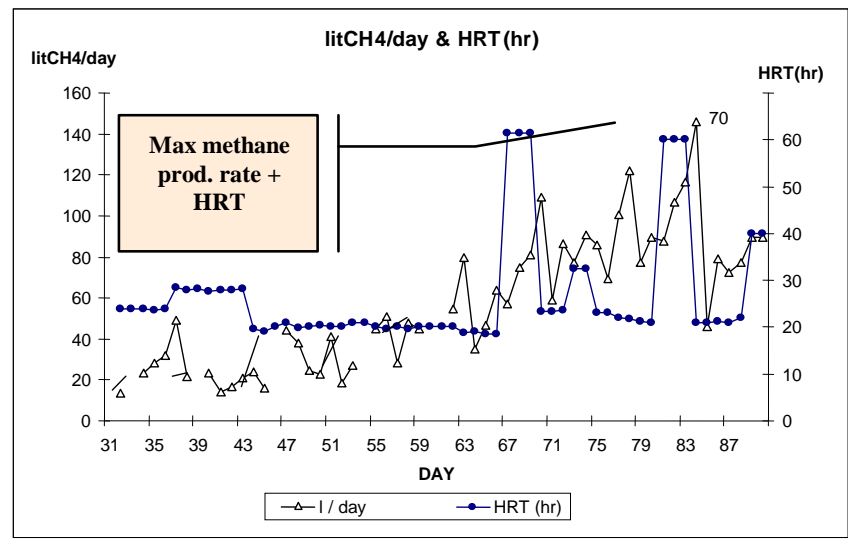

Fig. 5. Methane production rate and HRT.

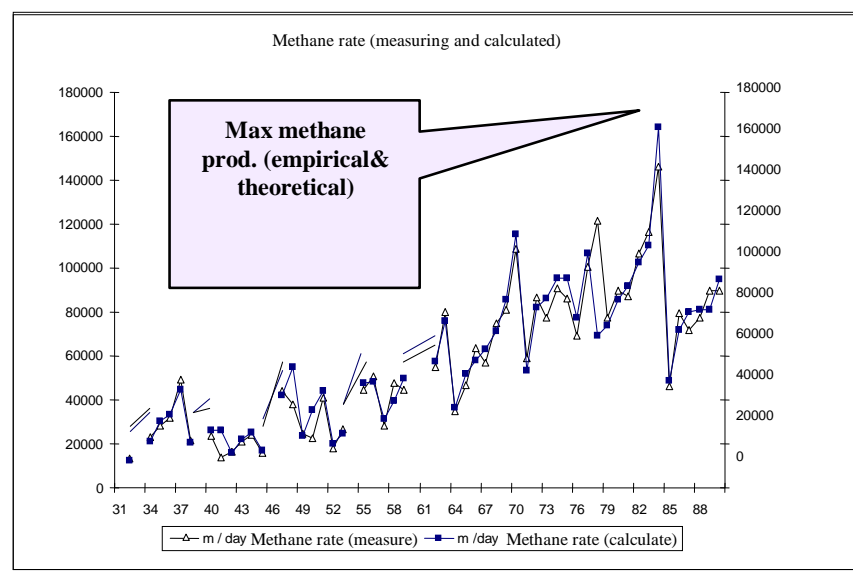

Fig. 6. Methane production rate (empirical \& theoretical).

Circulating the leachate in 4 stages in one month, hydraulic retention time and efficiency increases. When OLR is $14.9 \mathrm{~kg}$ $\mathrm{COD} / \mathrm{m}^{3}$ and influent COD is $17177.42 \mathrm{mg} / \mathrm{l}, 147063 \mathrm{ml} /$ day biogas and $108827 \mathrm{ml} /$ day methane gas in the $70^{\text {th }}$ day, With the COD removal efficiency of $75 \%$. The loading rate is increased when we have biogas production and when $\mathrm{COD}_{\text {in }}$ and OLR are respectively $19840 \mathrm{mg} / 1$ and $22.5 \mathrm{~kg} \mathrm{COD} / \mathrm{m}^{3}$ with the hydraulic retention time of $21.2 \mathrm{hr}$, the removal efficiency is $40 \%$, biogas and methane production rate are respectively $164570 \mathrm{ml} /$ day and $121782 \mathrm{ml} /$ day in the $78^{\text {th }}$ day. In $\mathrm{COD}_{\text {removal }}$ and OLR equals to $245113.756 \mathrm{mg} /$ day and $22.55 \mathrm{~kg} \mathrm{COD} / \mathrm{m}^{3}$, gas production rate (biogas and methane) respectively are $197485 \mathrm{ml} /$ day and $146139 \mathrm{ml} /$ day within $84^{\text {th }}$ day with removal efficiency of $64 \%$ and 60 hour circulation. After this stage, although loading rate is increased, 
there is a huge amount of decreasing in energy production that the gas production rate falls down and illustrate a shock in system which means that system cannot resist against the loading shock any more [13].

In Fig. 5, methane gas production rate (lit/day) in correlation with hydraulic retention time (HRT) and in Fig. 6 the amount of empirical and theoretical methane gas production are shown and the theoretical conclusions, confirm laboratory test's results in pilot [13].

\section{RESULTS AND DISCUSSION}

Leachate As it is shown in Fig. 7, generated biogas volume in beginnings is lower and is increasing by time. It is as a result of getting more compatibility microorganisms with the environment. But after a while, its increase rate is negligible because of shocks introduced to the system as a result of input load, high concentration of $\mathrm{H}_{2} \mathrm{~S}$, potential presence of Oxygen, and changes in $\mathrm{pH}[14]$.

At the beginning OLR is equal to $5.9 \mathrm{~kg} \mathrm{COD} / \mathrm{m}^{3}$, efficiency of system stands at $72.9 \%$ and biogas and methane gas production rate are $66583 \mathrm{ml} /$ day and $49272 \mathrm{ml} /$ day, respectively. Increasing the influent COD up to $8395 \mathrm{mg} / \mathrm{l}$ and OLR to $7.1 \mathrm{~kg} \mathrm{COD} / \mathrm{m}^{3}$; make a decrease in efficiency about $48 \%$, and biogas and methane gas production rate decrease to $31633 \mathrm{ml} /$ day and $23409 \mathrm{ml} /$ day, respectively. After this stage when we increase OLR and COD, the removal efficiency varies between 40 to $60 \%$ and 15934 to $54704 \mathrm{ml} \mathrm{CH}_{4} /$ day.

When OLR is $14.9 \mathrm{~kg} \mathrm{COD} / \mathrm{m}^{3}$ and influent COD is $17177.42 \mathrm{mg} / \mathrm{l}, 147063 \mathrm{ml} /$ day biogas and $108827 \mathrm{ml} /$ day methane gas are generated in the $70^{\text {th }}$ day. In that time COD removal efficiency stands at about $75 \%$. The loading rate is increased when there is biogas production and when $\mathrm{COD}_{\text {in }}$ and OLR are respectively $19840 \mathrm{mg} / \mathrm{l}$ and $22.5 \mathrm{~kg} \mathrm{COD} / \mathrm{m}^{3}$ with the hydraulic retention time of $21.2 \mathrm{hr}$, the removal efficiency is $40 \%$, biogas and methane production rate are respectively $164570 \mathrm{ml} /$ day and $121782 \mathrm{ml} /$ day in the $78^{\text {th }}$ day. In COD $_{\text {removal }}$ and OLR equals to $245113.756 \mathrm{mg} /$ day and $22.55 \mathrm{~kg} \mathrm{COD} / \mathrm{m}^{3}$, gas production rate (biogas and methane) are $197485 \mathrm{ml} /$ day and $146139 \mathrm{ml} /$ day respectively; within $84^{\text {th }}$ day with removal efficiency of $64 \%$ and 60 hour circulation. After this stage, although loading rate is increased, there is a huge amount of decreasing in energy production that the gas production rate falls down and illustrate a shock in system which means that system cannot resist against the loading shock any more.

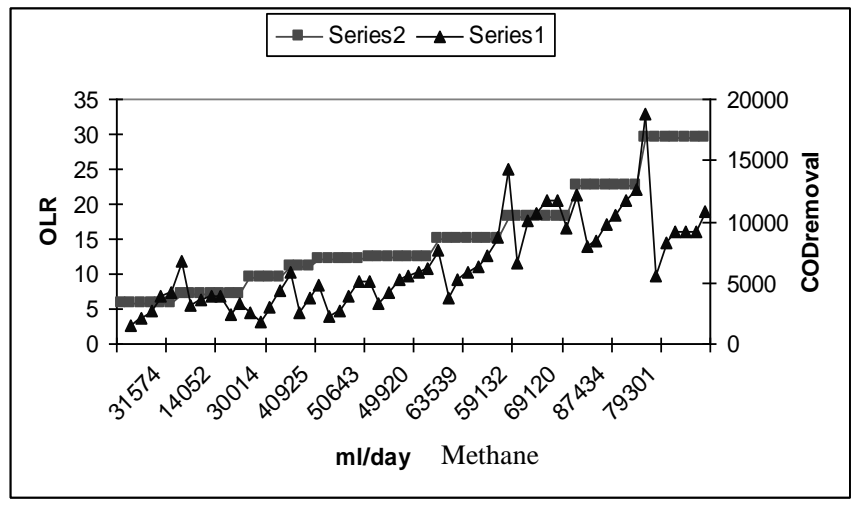

Fig. 7. $\mathrm{CH} 4$ changes with COD removal and OLR.
Trend-lines for each step have been provided with exponential, linear, and different polynomial curves. The best fitted curve is a polynomial curve with order 4 . As an example, for OLR of 22.9, the best fitted trend for estimating methane production (ml/day) is $1310.4 t^{4}-23696 t^{3}+151021 t^{2}$ $390100 t+404387$. Inwhich ' $t$ ' is time (day). Table II shows the models with different OLRs.

TABLE II: METHANE GENERATION MODELLING

\begin{tabular}{|c|c|c|}
\hline OLR & Trend Line (methane (ml/day), $t$ (day)) & $R^{2}$ \\
\hline 22.9 & $\begin{array}{l}\text { Methane }=1310.4 t^{4}-23696 t^{3}+151021 t^{2}-390100 t+ \\
404387\end{array}$ & 0.8549 \\
\hline 18.1 & $\begin{array}{l}\text { Methane }=607.5 t^{4}-11675 t^{3}+76536 t^{2}-195931 t+ \\
237318\end{array}$ & 0.7517 \\
\hline 14.9 & $\begin{array}{l}\text { Methane }=763.77 t^{4}-13580 t^{3}+85198 t^{2}-212415 t+ \\
218918\end{array}$ & 0.8999 \\
\hline 12.3 & $\begin{array}{l}\text { Methane }=516.97 t^{4}-8817.7 t^{3}+51890 t^{2}-118332 t+ \\
124291\end{array}$ & 0.7587 \\
\hline 12.1 & $\begin{array}{l}\text { Methane }=1299.4 t^{4}-18223 t^{3}+92640 t^{2}-192634 t+ \\
157843\end{array}$ & 1 \\
\hline 9.5 & Methane $=-3674.5 t^{3}+33070 t^{2}-81457 t+75962$ & 1 \\
\hline 7.1 & $\begin{array}{l}\text { Methane }=468.94 t^{4}-7915.3 t^{3}+47241 t^{2}-118852 t+ \\
127823\end{array}$ & 0.9562 \\
\hline 5.9 & $\begin{array}{l}\text { Methane }=-83.25 t^{4}+1205.2 t^{3}-6267.8 t^{2}+18642 t- \\
7062\end{array}$ & 1 \\
\hline
\end{tabular}

Average methane generation rate with OLR of 7.2 during has been observed about 22 1/day [9]. Utilizing introduced model, considering model for OLR 7.1 and $t=3.5$ days; methane production is calculated about $21545 \mathrm{ml} /$ day. Also for OLR of 12.8 observed methane rate is $46 \mathrm{l} / \mathrm{day}$ and it estimation by using equation for $\mathrm{OLR}=12.3$ is calculated about $45300 \mathrm{ml} /$ day. Its show a proper sensitive analysis and almost accurate estimation even with other studies.

\section{CONCLUSION}

The results of this research represent that:

- Methane production is produced at maximum rate when COD removal rate is at maximum. Soluble COD in digestion converted to sludge and biogas, when removal amount is increased, gas production is increased too. Thus, these tows happen together in the $84^{\text {th }}$ day. When $\mathrm{COD}_{\text {removal }}$ is $12605.4 \mathrm{mg} / \mathrm{l}$ or $315261.054 \mathrm{mg} / \mathrm{day}$, biogas and methane gas production rate are 197485 $\mathrm{ml} /$ day and $146139 \mathrm{ml} /$ day. In continuous regime, the average amount of methane gas production is $74 \%$ or $383 \mathrm{ml}$ methane per each gram COD removal;

- GFG instrument is used to measure the percentage of methane gas production, has a sensor to measure hydrogen sulfide and when its amount is high (like 112 ppm) it shows that sulfate concentration is high in leachate, which is toxic element and should be controlled to have an appropriate amount of methane gas production;

- Series of polynomial models with order four for different OLRs can be developed to estimate the methane generation rate.

\section{REFERENCES}

[1] K. J. Kennedy, M. F. Hamoda, and S. G. Guiot, "Anaerobic treatment of leachate using fixed film and sludge bed systems," J. Water Pollution Control, vol. 60, no. 9, pp. 1675-1683, 1998. 
[2] M. Sabour, H. Kamalan, and S. Pasdar, "Investigation on effective parameters on methane gas production out of landfill leachate treatment," Amirkabir Journal, vol. 69, pp. 1-8, 2007.

[3] L. W. Hulshoff-Pol, S. I. Castro Lopes, and G. Lettinga, "Anaerobic sludge granulation," Water Research Journal, vol. 38, issue 6, pp. 1376-1389, 2004.

[4] Inventory of greenhouse gas emissions and sinks 1990-1997. Office of Policy, Planning, and Evaluation. U.S. Environmental Protection Agency, [Online].

Available: http://www.epa.gov/globalwarming/inventory/index.html

[5] A. Sadamasa, I. Atushi, H. Shigeru, Y. Hideshi, and K. Shigehiko, "Emissions in combustion of lean methane-air and biomass-air mixtures supported by primary hot burned gas in a multi-stage gas turbine combustor," in Proc. the Combustion Institute 31, 2007, pp. 3131-3138.

[6] EPA. Sources and emissions. (2008). [Online]. Available: http://www.epa.gov/methane/sources.html

[7] H. Kamalan and A. Abedin, "Prediction of municipal landfill greenhouse gases emission utilizing weighted residual method," presented at International Conference on Environmental Pollution and Remediation, Ottawa, Canada, 2011.

[8] J. T. V. Grotenhuis and J. C. Kissel, "Role of substrate concentration in particle size distribution of methanogenic granular sludge in UASB reactors," Water Research Journal, vol. 25, issue 1, pp. 21-27, 1991.

[9] U. Marchaim, Biogas Processes for Sustainable Development, FAO, 1992.

[10] F. L. Burton, H. D. Stensel, et al., Wastewater Engineering Treatment \& Reuse, McGraw-Hill, fourth edition, 2003.

[11] G. Lettinga, S. Rebac, S. Parshina, A. Nozhevnikova, B. Jules, V. Lier, and J. M. Stams, "High-rate anaerobic treatment of wastewater at low temperatures," Applied and Environmental Microbiology, vol. 65, no 4, pp. 1696-1702, April 1999.

[12] Standard Methods for the Examination of Water and Wastewater, joint of American Public Health Association, the American Water Works Association, and the Water Environment Federation, 2004.

[13] M. Sabour, H. Kamalan, and S. Pasdar, "Investigation on effective parameters on methane gas production out of landfill leachate treatment," Amirkabir Journal, vol. 69, pp. 1-9, 2008.

[14] O. Nuri and D. Sponza, "Anaerobic/aerobic treatment of municipal landfill leachate in sequential two-stage up-flow anaerobic sludge blanket reactor (UASB)/completely stirred tank reactor (CSTR) systems," Process Biochemistry, 2004.

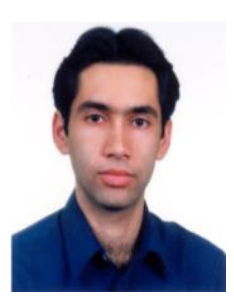

Hamidreza Kamalan has got his Ph.D. degree on civil and environmental engineering at $\mathrm{K}$. N. Toosi University of Technology.

$\mathrm{He}$ is an assistant professor at Islamic Azad University- Pardis Branch, Tehran, Iran and a member of APCBEEs. His publications consist of two books, 13 journal papers, and 15 conference papers. His book on the World Bank project management experience in Iran is a pioneer book in this field. He has been a member of technical committee of many conferences.

Dr. Kamalan is a member of variety professional societies such as APCBEES, Economic-Energy Society of Iran, Iran Civil Engineering Society, etc. He has been awarded as the best professor on 2011 and as the best researcher on 2013 at civil engineering group, Islamic Azad University, Pardis Branch. 


\section{Energy Policy}


